\title{
Perunantyvi- ja märkämätää aiheuttavaa Erwinia-lajistoa kartoitetaan
}

\author{
Jaana Laurila ${ }^{1)}$, Tiina Joutsjoki ${ }^{1)}$, Ari Lehtinen ${ }^{1)}$, Virpi Ahola ${ }^{2)}$, Asko Hannukkala ${ }^{1)}$ ja Minna \\ Pirhonen ${ }^{3)}$ \\ ${ }^{1)}$ MTT, Kasvinsuojelu, 31600 Jokioinen \\ jaana.laurila@mtt.fi, asko.hannukkala@mtt.fi \\ ${ }^{2)}$ MTT, Biotekniikka- ja elintarviketutkimus, 31600 Jokioinen \\ ${ }^{3)}$ Helsingin yliopisto, Soveltavan biologian laitos, PL 27, 00014 Helsingin yliopisto \\ minna.pirhonen@helsinki.fi
}

\section{Tiivistelmä}

Piilevä perunantyvi- ja märkämätä aiheuttaa ongelmia siemenperunan tuotannossa. MTT:n (Maa- ja elintarviketalouden tutkimuskeskus) ja Helsingin yliopiston välisessä yhteisprojektissa etsitään keinoja tyvi- ja märkämädän hallintaan bioteknisin menetelmin. Tutkimuksen tarkoituksena on selvittää, mikä on eri perunantyvi- ja märkämätää aiheuttavien Erwinia-bakteerilajien merkitys taudinaiheuttajana Suomessa ja mikä on mahdollisten luonnonkantojen rooli. Tyvi- ja märkämätää aiheuttavassa bakteerilajistossa on havaittu 2000-luvulla merkittäviä muutoksia Euroopan tärkeimmillä perunantuotantoalueilla.

Projekti aloitettiin kartoittamalla Erwinia-lajistoa keräämällä näytteitä sairaista perunan varsista ja mukuloista sekä jokivesistä Etelä-Suomesta ja Etelä-Pohjanmaalta. Näytteistä eristettiin bakteerikantoja puhdasviljelmiksi käyttäen pektaattia sisältävää alustaa. Eristetyt bakteerikannat tunnistettiin Erwinia-spesifisin PCR-testein. Vuoden 2004 kartoitus osoitti, että Suomen oloihin tyypillinen Erwinia carotovora alalaji atroseptica (Eca) oli vielä vallitseva tyvimädän aiheuttaja ja Erwinia carotovora alalaji carotovora (Ecc) märkämädän aiheuttaja. Lisäksi kartoitus paljasti, että lämpimimmissä ilmastoissa tyvi- ja märkämätää aiheuttavaa E. chrysanthemi -lajia (Ech) esiintyy nyt Suomessa. Uuden tulokaslajin osuus oli merkittävä kaikissa näytetyypeissä, vaikka se olikin rajoittunut muutamaan siemenerään. Kaikki vesinäytteistä eristetyt kannat olivat Ech:ta. Yleisesti Ech:ta on pidetty lämpimien ilmasto-olojen lajina, mutta on mahdollista, että Ech-lajista on kehittynyt viileässä ilmastossa menestyviä kantoja. On kuitenkin ilmeistä, että aggressiivisia Ech-kantoja löytyy meillä sekä perunoista että jokivedestä, joten Ech on todennäköisesti pysyvä ongelma, joka on otettava diagnostiikassa ja siementarkastuksessa huomioon.

Eristetyistä Erwinia-kannoista otettiin kattava otos ja ne sekvensoitiin 16S-23S rDNAvälialueelta käyttäen universaaleja alukkeita. Sekvensoidut kannat ryhmiteltiin fylogeneettisten puiden perusteella. Puiden estimointiin käytettiin Bayesiläisiä fylogenetiikan menetelmiä. Ryhmittely osoitti, että Eca-kannat olivat hyvin homologisia, kuten aikaisemmin on esitetty. Ecc- ja Ech-kannoissa oli enemmän vaihtelua. Tulkinnasta riippuen kummankin lajin kannat voitiin jaotella useampaan ryhmään. Jatkossa selvitetään, onko näillä ryhmillä yhteyttä taudinaiheuttamiskykyyn, jota tutkitaan mukula- ja varsimädätystesteillä kasvihuoneella sekä kenttäkokeissa. Mielenkiinnon kohteena on, voidaanko perunaerän tyvi- ja märkämädän puhkeamisriskiä ennakoida huomioiden bakteerikantojen geneettinen vaihtelu.

\section{Asiasanat}

PCR, sekvenssi, 16S-23S rDNA-välialue, virulenssi 


\section{Johdanto}

Perunantyvi- ja märkämätä ovat yhä edelleen kotimaisen siemenperunatuotannon pahin laatuongelma. Tyvimädän esiintyminen sertifioidussa siemenperunassa on heikentänyt luottamusta kotimaisen siemenen laatuun, lisännyt paineita ulkomaisen siemenperunan tuontiin ja haitannut suomalaisen siemenperunan lupaavilta näyttäneitä vientimahdollisuuksia. Lisäksi märkämätä aiheuttaa vuosittain merkittäviä varastohävikkejä ruokaperunateollisuudessa. Suurissa varastoissa yksikin märkämätäinen raaka-aine-erä voi aiheuttaa suunnatonta tuhoa. Mätänevät mukulat hajoavat visvaiseksi bakteerimassaksi, joka valuu nopeasti lähiympäristöön ja alun perin terveetkin mukulaerät saavat tartunnan ja mätänevät.

Tyvimädäksi kutsutaan emomukulasta alkavaa ja siitä perunan varsiin leviävää tyven mustumista ja mätänemistä, kun taas mukuloiden mätänemistä kutsutaan märkämädäksi. Erwiniasuvun bakteereista perunalla esiintyvät E. carotovora alalaji atroseptica (Eca), E. carotovora alalaji carotovora (Ecc) ja E. chrysanthemi (Ech). Uusimmassa bakteeriluokituksessa näiden lajien katsotaan kuuluvan Pectobacterium-sukuun (Gardan ym. 2003). Kaikki kolme Erwinia-bakteeria kykenevät aiheuttamaan märkämätää, mutta tyvimätää pystyvät aiheuttamaan yleensä vain Eca ja Ech (Pérombelon \& Kelman 1987). Suomessa on näihin päiviin asti pidetty tyypillisten tyvimätäoireiden aiheuttajana Eca-alalajia. Mukuloiden märkämädän syypäänä on pidetty Eca:n lisäksi Ecc:tä. Maailmalla Ech on aiheuttanut oireita ja tuhoja märissä oloissa yli $25^{\circ} \mathrm{C}: n$ lämpötiloissa trooppisessa ja subtrooppisessa ilmastossa. 2000-luvulla tyvi- ja märkämätää aiheuttavassa bakteerilajistossa on havaittu merkittäviä muutoksia Euroopan tärkeimmillä perunantuotantoalueilla. Hollannissa tehdyissä toistaiseksi julkaisemattomissa tutkimuksissa Ecc on usein aiheuttanut lakastumisoireita ja joskus tyypillisiä tyvimätäoireita (van der Wolf, henkilökohtainen tiedonvaihto lokakuussa 2003). Lisäksi Ech:n merkitys tyvi- ja märkämädän aiheuttajana on kasvanut.

MTT:n ja Helsingin yliopiston yhteisessä projektissa etsitään keinoja tyvi- ja märkämädän hallintaan bioteknisin menetelmin. Tutkimuksen tarkoituksena on selvittää, mikä on eri perunantyvija märkämätää aiheuttavien Erwinia-lajien merkitys taudinaiheuttajana Suomessa ja mikä on mahdollisten luonnonkantojen rooli. Eristettyjen Erwinia-kantojen taudinaiheuttamiskyvyn vaihtelua tutkitaan mukulanmädätyksin ja varsitestein.

\section{Aineisto ja menetelmät}

Projekti aloitettiin v. 2004 kartoittamalla Erwinia-lajistoa keräämällä näytteitä sairaista perunan varsista ja mukuloista sekä jokivesistä Etelä-Suomesta ja Etelä-Pohjanmaalta. Varsia oli noin 50, mukulanäytteitä 16 ja vesinäytteitä 26 kappaletta. Näytteistä eristettiin bakteerikantoja puhdasviljelmiksi käyttäen pektaattia sisältävää CVP-S2-alustaa. Erwinia-lajeiksi eristetyt bakteerikannat tunnistettiin laji- ja alalajispesifisillä PCR-testeillä: Eca-spesifinen PCR (De Boer \& Ward 1995), Ecc-spesifinen PCR (Rantanen ym., julkaisematon) ja Ech-spesifinen PCR (Nassar ym. 1996).

Eristetyistä kannoista otettiin kattava otos (Eca $42 \mathrm{kpl}$, Ecc $29 \mathrm{kpl}$ ja Ech $17 \mathrm{kpl}$ ), ja ne sekvensoitiin 16S-23S rDNA-välialueelta käyttäen universaaleja alukkeita (Fessehaie ym. 2002). Sekvenssit rinnastettiin Dialign-ohjelmalla (Morgenstern 1999). Rinnastetuille sekvensseille muodostettiin fylogeneettinen puu käyttämällä MrBayes-ohjelmaa (Huelsenbeck \& Ronquist 2001; Ronquist \& Huelsenbeck 2003). Kantojen PCR-tulosten luotettavuus varmistettiin vertaamalla sekvenssejä GenBank-tietokannan (Benson ym. 2005) sekvensseihin Blast-hakujen (McGinnis \& Madden 2004) avulla.

\section{Tulokset ja tulosten tarkastelu}

Varsinäytteissä eristetyistä Erwinia-kannoista Eca:n osuus oli runsaat 40 \%, Ecc:n 30 \% ja Ech:n osuus oli noin 25 \% (Kuva 1a). Muutamissa näytteissä esiintyi samanaikaisesti kahta bakteerilajia. Mukulanäytteistä eristetyistä kannoista noin 50 \% oli Ecc:tä, noin 40 \% oli Eca:a ja loput oli Ech:ta (Kuva 1b). Seitsemästä jokivesinäytteestä saatiin eristettyä Erwinia-kantoja, ja ne kaikki olivat PCRtestien mukaan sekä Ecc- että Ech-positiivisia tai pelkästään Ech-positiivisia. Edellisessä 1980-luvulla tehdyssä Erwinia-kartoituksessa suomalaisissa siemenperunoissa Eca-alajin osuus oli 67 \%, ja Ecc:tä eristettiin muutamista varsinäytteistä (Harju \& Kankila 1993). Silloin Ech-lajia ei löytynyt Suomesta. Vuoden 2004 kartoitus osoitti, että Suomen oloihin tyypillinen Eca oli vielä vallitseva tyvimädän 
aiheuttaja ja Ecc märkämädän aiheuttaja. Lisäksi kartoitus paljasti, että lämpimimmissä ilmastoissa tyvi- ja märkämätää aiheuttavaa E. chrysanthemi -lajia (Ech) esiintyy nyt Suomessa. Uuden tulokaslajin osuus oli merkittävä kaikissa näytetyypeissä, vaikka se olikin rajoittunut alun perin ulkomailta tuotuihin siemeneriin. Yleisesti Ech:ta on pidetty lämpimien ilmasto-olojen lajina, mutta on mahdollista, että Ech-lajista on kehittynyt viileässä ilmastossa menestyviä kantoja. On kuitenkin ilmeistä, että aggressiivisia Ech-kantoja löytyy sekä Suomessa lisätyistä siemenistä että jokivesistä, joten Ech on todennäköisesti pysyvä ongelma, joka on otettava diagnostiikassa ja siementarkastuksessa huomioon.

Erwinia-tilanne on myös muuttunut Euroopan tärkeimmillä perunantuotantoalueilla. Viime vuosina mm. Hollannissa Ech-bakteeria on todettu jopa 60-70 \% tyvimätäisissä perunoissa (van der Wolf, suullinen tiedonanto lokakuussa 2005). Vuonna 2003 Ranskassa Ech:n osuus tyvimätäisissä varsissa vaihteli 13,5-80 \% riippuen näytteenkeräysalueesta (Hélias ym. 2004) ja Belgiassa Ech:n osuus oli 38 \% (Dupuis ym. 2005). Ech:n lisäksi Ecc:n merkitys on mahdollisesti kasvanut. Hollannissa tehdyissä tutkimuksissa on löydetty tyvimädän tyyppisiä oireita aiheuttavia Ecc-kantoja (van der Wolf, henkilökohtainen tiedonvaihto lokakuussa 2003). Myös muut tutkimusryhmät ovat eristäneet Ecc:tä sairaista varsinäytteistä (Hélias ym. 2004; Dupuis ym. 2005).

a)

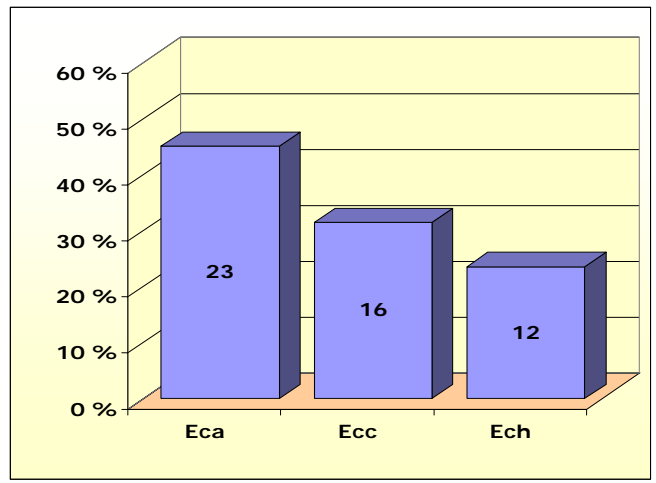

b)

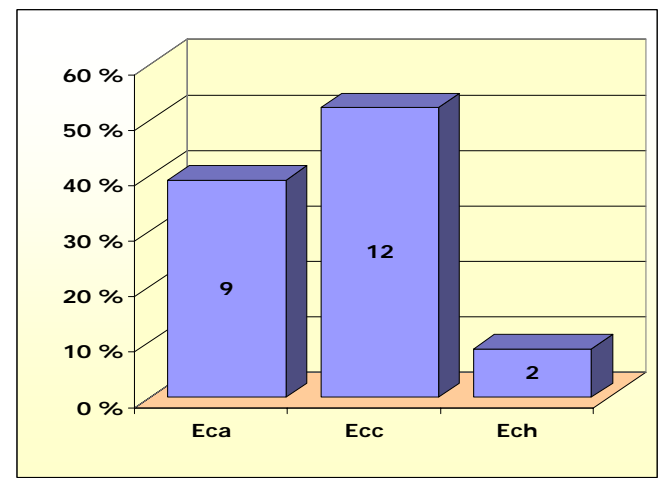

Kuva 1. Erwinia-lajien esiintyminen a) kesällä 2004 kerätyissä varsinäytteissä ja b) 2004-2005 kerätyissä mukulanäytteissä. Kuvan pylväissä näkyvä luku on eristettyjen bakteerikantojen lukumäärä.

16S-23S rDNA-välialueelta sekvensoidut kannat ryhmiteltiin fylogeneettisten puiden perusteella (Kuva 2). Eca-kantojen sekvenssit olivat lähes identtisiä, joten ne muodostivat vain yhden ryhmän. Tulos on yhtenäinen muualla saatujen tulosten kanssa (Darrasse ym. 1994). Ecc- ja Ech-kannoissa oli enemmän vaihtelua. Tulkinnasta riippuen kummankin lajin kannat voitiin jaotella useampaan ryhmään. Poikkeavimman Ech-ryhmän kannat olivat vedestä eristettyjä kantoja. Sekvenssien perusteella vesikantoja oli kahdenlaisia: osa kannoista oli aivan samanlaisia varsi- ja mukulanäytteistä eristettyjen kantojen kanssa ja osalla oli varsi- ja mukulakantoihin verrattuna lyhyt insertti. Blasttietokantahakujen mukaan kaikki vesikannat olivat Ech:ta. Samoin rasvahappoanalyysin (Soveltavan kemian ja mikrobiologian laitos, HY) mukaan kannat olivat Ech:ta, mutta ne olivat eri biotyyppiä. Joki- ja pintavesistä löydetään yleisesti Ecc:ta ja Ech:ta (Cother ym. 1992; Norman ym. 2003). Vesistä eristetyissä Ech-kannoissa on ollut kantavaihtelua rasvahappo- ja DNA-testien mukaan, ja osa vesistä eristetyistä kannoista on ollut samanlaisia mukuloita mädättävien kantojen kanssa (Cother ym. 1992). On mahdollista, että Erwinia-lajeja sisältävät vedet voivat toimia infektiolähteenä, jos niitä käytetään perunapeltojen kasteluvetenä. Jatkossa tässä projektissa tutkitaan, ovatko kaikki vesikannat kykeneviä mädättämään perunaa. Osa niistä on ilmeisesti perunan taudinaiheuttajia, osa muiden kasvien patogeenejä. 


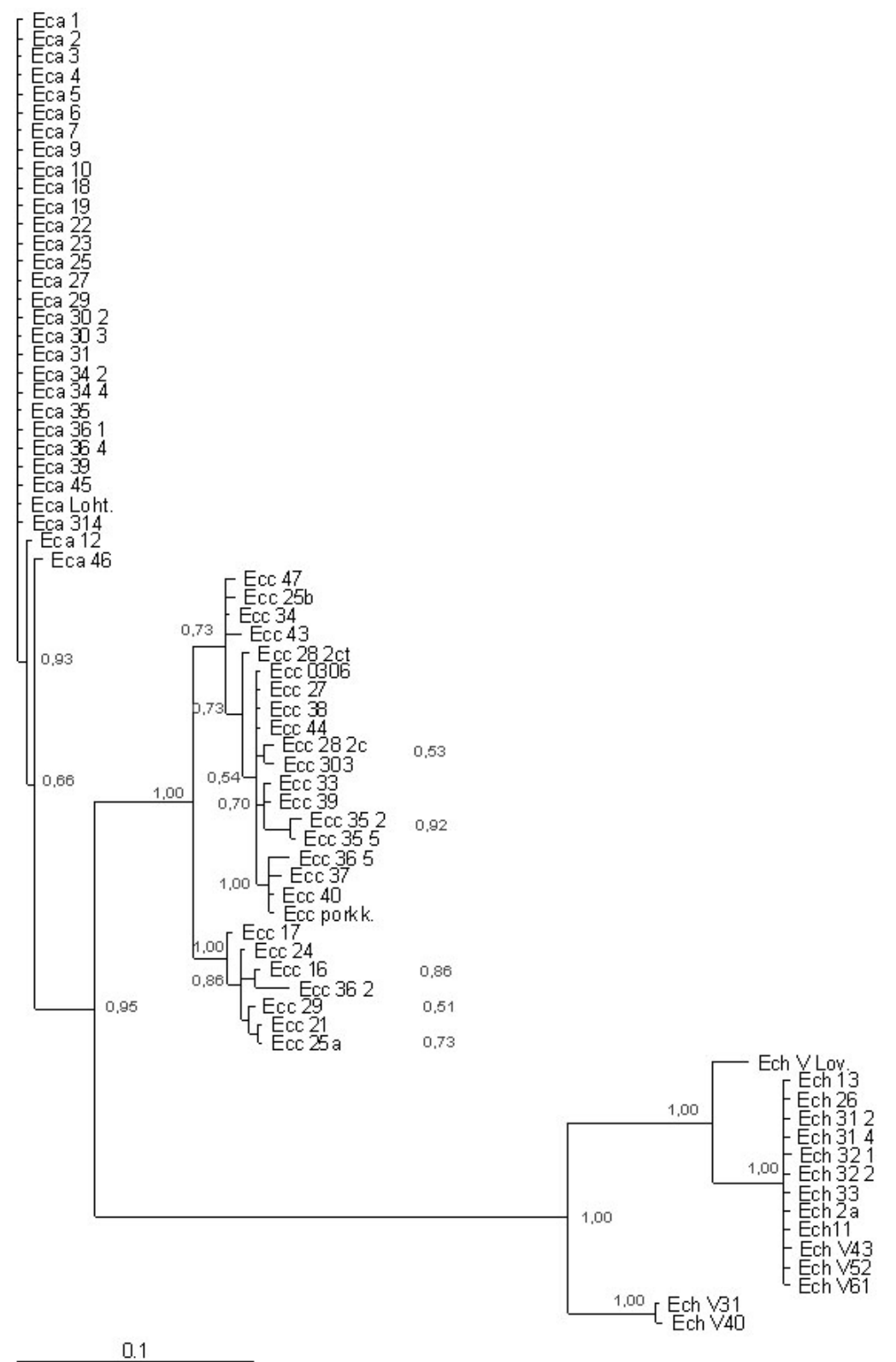

Kuva 2. Eca-, Ecc- ja Ech-kantojen 16S-23S rDNA-välialuesekvensseille muodostettu fylogeneettinen puu. Puun oksissa olevat luvut ovat posterioritodennäköisyyksiä ja kuvaavat haaran luotettavuutta. Kuvassa ei ole esitetty kaikkia identtisiä Eca-kantoja. (V = vesinäyte).

Myös muiden Ecc- ja Ech-kantojen kuin vesikantojen virulenssin vaihtelua tutkitaan. Virulenssitestauksen tarkoituksena on selvittää eri kantojen kyky ja erot aiheuttaa tyvi- ja märkämätäoireita perunalla sekä se, löytyykö ympäristöstä Erwinia-sukuisia bakteereita, jotka eivät aiheuta lainkaan tautia perunalla. Selvitetään, onko muodostuneilla Ecc- ja Ech-ryhmillä (Kuva 2) mitään biologista merkitystä mm. tutkimalla kantojen taudinaiheuttamiskykyä mukulanmädätyksin ja varsitestein kasvihuoneella sekä kenttäkokeissa. Kantojen virulenssin vaihtelua verrataan sekvenssitietoon. Mielenkiinnon kohteena on, voidaanko perunaerän tyvi- ja märkämädän puhkeamisriskiä ennakoida bakteerikantojen geneettisen vaihtelun avulla. Erityismielenkiinnon kohteena on, koska Ecc on yleinen bakteeri luonnossa, pystyykö Ecc aiheuttaman tyvimätää vai onko Ecc pelkästään haavaloinen perunanvarressa. Tätä tutkitaan sekä kasvihuone- että peltokokein. 


\section{Johtopäätökset}

Perunantyvi- ja märkämätää aiheuttaa Suomessa nyt E. carotovora -lajin (Eca ja Ecc) lisäksi toinen Erwinia-laji, E. chrysanthemi (Ech). Yleisesti Ech:ta on pidetty lämpimien ilmasto-olojen lajina, mutta on mahdollista, että Ech-lajista on kehittynyt viileässä ilmastossa menestyviä kantoja. Ech on todennäköisesti pysyvä ongelma, joka on otettava diagnostiikassa ja siementarkastuksessa huomioon. Suomesta eristetyt Eca-kannat olivat homologisia 16S-23S rDNA-välialueen sekvenssien perusteella. Ecc- ja Ech-kannoissa oli enemmän vaihtelua. Jatkossa Ecc- ja Ech-kantojen taudinaiheuttamiskykyä tutkitaan mukulanmädätyksin ja varsitestein kasvihuoneella sekä kenttäkokein. Mielenkiinnon kohteena on, voidaanko perunaerän tyvi- ja märkämädän puhkeamisriskiä ennakoida huomioiden bakteerikantojen geneettinen vaihtelu.

\section{Kirjallisuus}

Benson, D.A., Karsch-Mizrachi, I., Lipman, D.J., Ostell, J. \& Wheeler, D.L. 2005. GenBank. Nucleic Acids Res. 33: D34-38.

Cother, E.J., Bradley, J.K., Gillings, M.R. \& Fahy, P.C. 1992. Characterization of Erwinia chrysanthemi biovars in alpine water sources by biochemical properties, GLC fatty acid analysis and genomic DNA fingerprinting. J. Appl. Bacteriol. 73: 99-107.

Darrasse, A., Kotoujansky, A. \& Bertheau, Y. 1994. Isolation by genomic subtraction of DNA probes specific for Erwinia carotovora subsp. atroseptica. Appl. Environ. Microbiol. 60: 298-306.

De Boer, S.H. \& Ward, L.J. 1995. PCR detection of Erwinia carotovora subsp. atroseptica associated with potato tissue. Phytopathology 85: 854-858.

Dupuis, B., Michelante, D., Garcia, N., Nimal, C. \& Stilmant, D. 2005. Potato contamination by pectinolytic in the Walloon area in 2003 and 2004. In: E. Ritter, A. Carrascal (eds). 16th Triennial Conference of the EAPR. European Association for Potato Research. EAPR-2005, July 17 to 22, 2005, Bilbao, Spain. Abstracts of papers and posters II. Poster presentations. Bilbao: EAPR.

Fessehaie, A., De Boer, S.H. \& Lévesque, C.A. 2002. Molecular characterization of DNA encoding 16S-23S rRNA intergenic spacer regions and 16S rRNA of pectolytic Erwinia species. Can. J. Microbiol. 48: 387-398.

Gardan, L., Gouy, C., Christen, R. \& Samson, R. 2003. Elevation of three subspecies of Pectobacterium carotovorum to species level: Pectobacterium atrosepticum sp. nov., Pectobacterium betavasculorum sp. nov. and Pectobacterium wasabiae sp. nov. Int. J. Syst. Evol. Microbiol. 53: 381-391.

Harju, P. \& Kankila, J. 1993. Erwinia carotovora contamination of Finnish seed potatoes and the prevalence of bacterial subspecies and serogroups. Agric. Sci. Finl. 2:345-352.

Hélias, V., Le Roux, A.C., Boishardy, M., Aujean, J.M., Copin, P., Perramant, M. \& Montfort, F. 2004. Erwinias causing blackleg in France: species/subspecies and their distribution in 2003. In: E.A.P.R. pathology section meeting, 11-16 July 2004, Lille, France. Abstracts.

Huelsenbeck, J.P. \& Ronquist, F. 2001. MRBAYES: Bayesian inference of phylogenetic trees. Bioinformatics 17: 754-755.

McGinnis, S. \& Madden, T.L. 2004. BLAST: at the core of a powerful and diverse set of sequence analysis tools. Nucleic Acids Res. 32: W20-25.

Morgenstern, B. 1999. DIALIGN 2: improvement of the segment-to-segment approach to multiple sequence alignment. Bioinformatics 15: 211-218.

Nassar, A., Darrasse, A., Lemattre, M., Kotoujansky, A., Dervin, C., Vedel, R. \& Bertheau, Y. 1996. Characterization of Erwinia chrysanthemi by pectinolytic isozyme polymorphism and restriction fragment length polymorphism analysis of PCR-amplified fragments of pel genes. Appl. Environ. Microbiol. 62:2228-2235.

Norman, D.J., Yuen, J.M.F., Resendiz, R. \& Boswell, J. 2003. Characterization of Erwinia populations from nursery retention ponds and lakes infecting ornamental plants in Florida. Plant Dis. 87: 193-196.

Pérombelon, M. C. M. \& Kelman, A. 1987. Blackleg and other potato diseases caused by soft rot Erwinias: proposal for revision of terminology. Plant Dis. 71:283-285.

Ronquist, F. \& Huelsenbeck, J.P. 2003. MrBayes 3: Bayesian phylogenetic inference under mixed models. Bioinformatics 19: 1572-1574. 